\title{
Marginal memories of Lebanon's Civil War: challenging hegemonic narratives in a small town in North Metn
}

\section{Carmen Hassoun Abou Jaoude and Daniele Rugo}

\begin{abstract}
This article focuses on the 'hidden public culture' formed by individual memories of violent conflicts, with particular reference to the Lebanese Civil War (1975-90). Taking memory as a terrain through which individuals can contest authoritarian governance and repressive memory scripts, the article argues that personal memories of ordinary citizens can contribute to illuminate the power relations that structure war memorialisations. Through a series of interviews, the article analyses militia practices in a small town in North Metn to challenge the idea that militias were merely defending a territory from external enemies. Militia abuses against the populations they were meant to defend during the Civil War are also used as a starting point to reflect on Lebanon's present. This case study is then used as a starting point to advocate for the use of personal memories in the research of violent conflicts as a way to broaden our understanding of conflict's lived experiences.
\end{abstract}

Keywords: Lebanese Civil War, individual memories, militia, conflict, lived experience.

Note on the authors:

Dr Carmen Hassoun Abou Jaoude is a political scientist, transitional justice expert, and former Head of Lebanon's office at the International Centre for Transitional Justice. She is also a lecturer at Saint Joseph University of Beirut, American University of Beirut, and Holy Spirit University of Kaslik. Since June 2020 she has been a member of Lebanon's National Commission for the Missing and Forcibly Disappeared Persons and a member of the advisory board of Act for the Disappeared, an NGO that is advocating for the clarification of the fate of the missing from the Lebanese Civil War.

Dr Daniele Rugo is an award-winning filmmaker and Reader in Film at Brunel University London and currently a Visiting Senior Fellow at the LSE and Visiting Professor at Sciences Po. His research focuses on conflict and sustainable peace and has been funded by AHRC, ESRC, and British Academy. About a War is his latest feature documentary. He is the author of two monographs, one edited volume, and several journal articles.

https://orcid.org/0000-0001-8606-9524

(C) The author(s) 2021. This is an open access article licensed under a

Creative Commons Attribution-NonCommercial-NoDerivs 4.0 Unported License 
'This is worse than the war', said Salma, a 72-year-old woman interviewed in North Metn. ${ }^{1}$ She was referring to the massive explosion that devastated Beirut on 4 August 2020. As a result of the blast, in a few seconds over 200 people were killed, 6,000 wounded, and 300,000 left homeless or displaced. Pending the results of an investigation, many in Lebanon blame the negligence and corruption of present and past Lebanese governments for the explosion. Almost 1,700 tons of nitrate ammonium were stored in the port for over six years, despite the authorities receiving a number of warnings as to the potential danger. In the aftermath, Salma and many others who like her had lived through Lebanon's Civil War (1975-90), have relived their experiences of the war's worst days. The blast has refreshed the trauma of the conflict and the following decades of Israeli bombings (in 1993, 1997, and 2006) and targeted assassinations (between 2004 and 2013). The conviction that the war never actually ended-despite the official cessation of hostilities in 1990-persists among the Lebanese. The idea is reinforced by ongoing political violence and by the fact that the warlords of yesteryear - protected by years of impunity - still monopolise both power and the official memory of the conflict.

Given this premise, this article contends that the 'hidden public culture' formed by the memories of ordinary individuals can play a crucial role in our understanding of Lebanon's past wars and present condition. Furthermore, the argument aims to illuminate more broadly how these memories can support a bottom-up understanding of violent conflicts and the narratives built in their course and aftermath. This article does not intend to neglect the importance of mnemonic socialisation, the idea that memories are constituted interactionally and that collective frameworks offer ways for individual experiences to be rationalised and validated. As Lorraine Ryan aptly summarises, 'our individual memory inescapably reflects group memory as we incorporate past inexperienced group elements into our own memory and construct our individual memories with society's explanatory tools' (2010: 157). The article therefore accepts the idea that 'memory is the product of conflicts, power struggles and social contestation, always fragile and provisional' (Bell 2009: 351).

However, as the case study presented here shows, a sustained encounter with ordinary individual memories of conflict, marginalised by elite discourses and official accounts, can challenge the idea of war as a spectacular/exceptional event and move our attention to everyday experiences and therefore everyday impacts of violence. When we invoke personal memories, we intend to emphasise those narratives that have not been sanctioned as authoritative, but also have not been accepted into national or even local discourses and maintain the potential to challenge official narratives and public discourses. It is not a matter of negating the interactive and 
shared nature of memory-making, but of shifting the focus onto how memories of ordinary individuals, excluded from official scripts and therefore marginal, can challenge the consolidation of hegemonic narratives and reopen the status and interpretation of those collective memories taken as given. The argument developed here attempts to show that, whilst memory is always predicated on the interaction between private/everyday/individual memories and official/collective ones, this interaction can take the form of a dispute, in particular when what is at stake is the legacy of a violent conflict. The article also aims to show how individuals' attachment to their own lived experiences (and the memories formed therein) can be a site of contestation of a dominant narrative that negates that lived experience. We focus on the Lebanese Civil War (1975-90) as exemplary of a protracted conflict that has a highly fragmented (if at all existent) national memory, dominated by accounts of the ruling political class. In this context, the marginal memories discussed above constitute both a site of resistance to political and sectarian elites and introduce a different understanding of the conflict.

Lebanon's post-conflict settlement (formalised in the 1989 Ta'if Agreement), has been to a large extent monopolised by the very political-military actors who fought the war. The Amnesty Law from 1991 — which has pardoned all crimes against civilians - has promoted a selective amnesia that has reinforced the narratives of specific leaders to the detriment of those of ordinary citizens. Political leaders have used and continue to use memory to advance their own local and geopolitical agendas and interests. As a consequence, the case of Lebanon allows for the study of situations where memory discourse becomes an explicit and pivotal tool for the construction of political subjectivities. A focus on personal memories underlines the importance of power relations in the construction of official narratives and the dissonances, omissions, and assumptions they facilitate. Since the end of the war, leaders and political parties have exercised a monopoly over which narratives of the conflict are accepted into public discourse. In the absence of a history textbook to explain the Civil War, this type of memory work has often been legitimised by State officials and institutions. Artistic productions, such as films and plays that have emphasised the dissonance between official and marginal narratives, have been the subject of explicit and implicit censorship. Nevertheless, over the years a lively and robust civil society has made efforts to challenge this censorship, whilst social media and street protests have contributed immensely to breaking the silence. Marginal memories have the potential to challenge hegemonic narratives in a country where warlords are still in power and instrumentalise the war memory for their own benefit. Sune Haugbolle, for instance, writes that political parties actively look for ways 
to inscribe their sectarian hagiographies of martyred leaders and soldiers in national history and symbolism. Nevertheless, these sectarian memory cultures, whether in East Beirut or in the Dahiya, were essentially defensive and divisive narratives of the past that claimed ownership of individual memories on the basis of sectarian identity. (2010: 79)

In Lebanon, memory work is often employed as a tool to nurture and corroborate sentiments of fear and resentment within parties' circles of clients and supporters. One could say that in the case of post-war Lebanon officially sanctioned memories are used to found the legitimacy of powerful figures who have transitioned from warlord to political leader. As Sune Haugbolle and Andres Hastrup note, 'official renderings of historical events frequently sit uneasily with lived experience of the communities and individuals who have suffered through oppression and violence' (Haugbolle \& Hastrup 2008: 141). Bell's critique that scalar differences should be emphasised as much as similarities is also pertinent to our argument, meaning that we should think of individual memories as operating in unique ways, rather than just assume that "the "collective memories" of large groups of people operate in ways analogous to those of small groups, and even (in a problematic psychologisation of the political) individual minds' (2009: 350).

While much has been written about the Lebanese Civil War, little has been done to understand the conflict through its everyday, social and cultural dimensions. Many studies have emphasised the role of leaders, local political and sectarian groups, and international actors in the war, ${ }^{2}$ but we know much less about the experiences, views, perceptions, and stories of ordinary people during the fifteen years of armed conflict. What was it like to live under the protection and authority of a local militia? How do

\footnotetext{
${ }^{2}$ The bibliography is too vast to be mentioned in full here, but it is worth noting some recent memoirs, written both by political-military leaders and members of various militias. For instance: Amine Gemayel (2020), Al-Ri'âssat al-Muqâwima, Muzakkarât (A resistant presidential mandate, Memoirs) (Manchourât Bayt al-Mustaqbal, Lebanon); Michel Aoun (2017) Ce que je crois; entretiens avec Désirée Sadek (Beyrouth, Fondation Michel Aoun); Georges Kassis (2019), Yawmiyât Shahida. Wafầ li abtâl al-mouqâwamat al-loubnaniya wa amâna lil haqiqa (Witness diaries. In loyalty to the heroes of the Lebanese resistance and in honesty to the truth) (Beirut, First volume, Dar Sa'er al-Mashreq); Yussef Bazzi (2007), Yasser Arafat m'a regardé et m'a souri (Paris, Verticales Éditions). In addition, a long list of biographies on political leaders could be compiled, including the recent: Nada Anid (2014), L'homme de cèdre: les trois vies de Samir Geagea (Paris, Calmann-Lévy); Michel Aoun (2007), Une certaine vision du Liban; entretiens avec Frédéric Dumont (Paris, Fayard); Igor Timofeev (2000), Kamal Jumblatt: Al-Rajul wa al-ustura (Kamal Jumblatt: the man and the legend) (Beirut, Dar An-Nahar); René Naba (1999), Rafic Hariri: un homme d'affaires premier ministre (Paris, L'Harmattan). It is also worth mentioning those works focusing on the war seen through the lens of political parties and militias, such as the two volumes of Alain Ménargues' (2004) Les secrets de la guerre du Liban (Paris, Albin); Mara Albrecht \& Akar Bassel (2016), The Power of Remembrance: Political Parties, Memory and Learning About the Past in Lebanon (Louaize, Forum ZFD and Center for Applied Research in Education at Notre Dame University); and Franck Mermier \& Sabrina Mervin (eds) (2012), Leaders et partisans au Liban (Paris, Karthala-IFPO; Beyrouth, IISMM).
} 
they perceive the conflict and its actors today? What have they transmitted to their children, grandchildren, and families since the official end of the war? How do they believe violent conflicts could be prevented in Lebanon in the present and the future?

Interrogating ordinary individuals' memories could offer ways to reinterpret crucial moments of the conflict and revisit assumptions as to the conflict's dynamics. In Lebanon's case, one of the most resilient narratives is the idea that sectarian militias functioned solely to protect civilians from the same community/religious confession in the areas they managed. During the war, many regions were under the control of the political and paramilitary factions that had replaced State authorities and sometimes operated in collusion with these. Due to the level of territorial fragmentation during the conflict, regions were also referred to as 'cantons', in reference to the Swiss federations. Political parties and their militias ruled these cantons with the professed mission to protect the local population from a threatening 'enemy'. Leaders often used this narrative to legitimise the militia's existence and mobilise support. This article aims to contribute to challenging these narratives about the past, gathering memories of ordinary people that often conflict with hegemonic narratives.

One of our interviewees, Dolly, 60 years old, recalls how the practice of kidnapping local businessmen and wealthy people to extract ransom was widespread. Dolly, who today is the mother of three young adults, says, 'My father was kidnapped multiple times by the local militia. They used to threaten him if he didn't give them the money they asked for. ${ }^{3}$ Her sister Ghada, a 61-year-old lawyer, harbours a deep-seated resentment towards the militia that abducted her father, but also numerous other people in her town, and committed abuses in the very region they were supposed to protect. These include imposing illegal taxes, seizing goods and products from stores, and creating a kind of 'arbitration court' that 'judged' people beyond the reach of the State's judiciary, extorting money and arbitrarily detaining people. Ghada explains that:

militiamen, some of whom we knew from our village, used to invade my father's store and take food or beverage supplies with the excuse that these had expired to re-sell them in their so-called cooperative stores or supermarkets. They robbed people, businesses and the Beirut port, which was controlled by Christian militias during the war. ${ }^{4}$

Ghada's father Habib who also owned a cinema had to pay a special tax for every ticket sold. The militiamen used to attend the movies without paying, but accepted they had to leave their weapons outside of the screening room, hanging in the cloakroom. 'They were even given a number to identify the "item", recalls Joe, 58 years old, who was a teenager at the time and used to help his family running the cinema. 'I remember that one day militiamen started shooting in the air inside the cinema, to

${ }^{3}$ Interview, North Metn, 24 July 2020.

${ }^{4}$ Interview, North Metn, 10 July 2020. 
frighten and intimidate people', says Fouad, who regularly visited the movie theatre, the only one in the region at that time. Fahed, 65 years old, a former employee at the cinema, recalls that 'once the screening of a film was interrupted by a group of armed men ordering people from the audience to get out and help filling sandbags for the militia in anticipation of a battle'.

What emerges from this study is that civilians within specific communities had to suffer various types of abuses and violations from the very same militias that were meant to protect them and this also in cases when the militia shared the community's sectarian affiliation. These people have almost never had the opportunity to question the formal narratives or to express their views and tell the story of their life during the decades of continuous conflicts. This research ${ }^{5}$ attempts to reverse this reality and explores individual narratives in a small town in North Metn, in what was called the 'Christian' or 'Eastern'6 region as a case study that could support a different understanding of the Lebanese conflict, its aftermaths, and the continuous state of turmoil and crisis, including the present predicament. The article is divided in three parts: the first section looks at the interplay between individual and collective memory; the second section focuses on the case study of a community in North Metn, a district in Mount Lebanon, to analyse how individual memories can demand a rewriting of national histories and become therefore sites of resistance; the third section broadens the scope to highlight how a focus on individual memories shifts our attention onto the everyday dimension of conflict.

\section{Individual and collective memories}

Cultural theorists have often been reluctant to accept the significance of individual memories or have sought to minimise their value (Green 2004: 41). Partly this is because individual memories often challenge the continuity and homogeneity that national narratives (in particular those enforced by the nation state) tend to pass off as natural. The testimonies collected here form part of a set of memories largely

${ }^{5}$ This article emerges from and shares the aims of the research project 'Memories from the Margins. Bottom-up Practices for Dealing with Conflict-Produced Heritage in Lebanon and Syria' (https://www. memoriesmargins.com).

${ }^{6}$ In the opening stages of the war, the capital Beirut was divided between West (with a majority Muslim population) and East (majority Christian population) along an imaginary line called 'demarcation line' or 'green line' in reference to the vegetation that had started growing in what had become a no-man's land. This divide was also then applied to the regions situated geographically to the West of Beirut (called also 'Muslim regions') and to the East of the capital ('Christian regions'). This divide was symbolic of the cleavages between the Lebanese people during the war that resulted in demographic transformation due to massive internal displacements. 
repressed and erased from public discourse by official narratives and accounts. It is significant that the social movements and protests that have animated Lebanese cities since October 2019 have freed the personal narratives related to militia practices and their leaders' behaviour. When people on the streets shouted 'All of them, means all of them', they aimed their chants precisely at those warlords who stand accused of replicating war practices in the time of peace. The rejection of political parties and leaders who have played a role during the conflict is indicative of this newly found liberation of marginal memories.

The capacity of individual memories to 'contest and critique cultural scripts and discourses' (Green: 2004: 42) is an obstacle to their inclusion in both public memory and in those analyses that assess its work. As Anna Green suggests, however, 'oral history allows us access to the range of expressive possibilities in a given society', but this implies a broadening of the horizon and requires that 'we remain open to the richness and variety of individual consciousness' (Green: 2004: 43).

The influence of the work of Maurice Halbwachs on memory studies is partially responsible for this resistance and the omissions this position has produced. As Ryan writes, the perception is that Halbwachs's work produces 'a complete negation of any autonomous individual agency or resistance' (2010: 155). Halbwachs emphasises the 'unity of outlook', assigning mnemonic agency to the group, which imposes its conventions on the individual remembering subject. Halbwachs ties memories of individuals tightly to social groups, thus giving weight to the primacy of collective memory. As Emily Keightley and Michael Pickering suggest, 'in memory studies, too often sight is lost of the individuals who engage in acts of remembering' (2012: 82).

Following Steve Stern's work on Pinochet's Chile (2010), Salwa Ismail in her analysis of memories of the Ba'ath generation in Syria suggests reading the relation of public and private as mediated by 'emblematic frameworks' (2018: 98). Ismail describes these as 'frames of recollection that enable individuals to make sense of their personal experiences and to locate these within remembrances of a collective or shared national life' (98). In this sense, then, interrogating personal narratives is important, because these show how 'personal and intimate everyday life experiences aggregate in the life of an individual to form a composite of the national experience' (122).

Jose Van Dijck's concept of 'personal cultural memory' moves a step further in considering personal memories as an autonomous way to negotiate and potentially challenge established national and public narratives. As Van Dijck writes, 'personal (re)collections are often subsumed as building blocks of collective history rather than being analysed in their own right' (2007: 2). The idea of personal cultural memory seeks to develop a path out of this impasse and Van Dijck defines it as follows: 'the acts and products of remembering in which individuals engage to make sense of 
their lives in relation to the lives of others and their surroundings, situating themselves in time and place' (6). Interestingly, Van Dijck also suggests that 'aspects of memory need to be explained from processes that derive from individual identities' (9). Attending to these processes might also help uncover the expressive nuances of memory, once this becomes narration. Aïda Kanafani-Zahar admirably captures the varying speeds of memory, its pauses and abrupt stops, but also its precipitating movements, 'once emerged, a memory possesses a fervor and a liveliness that provokes a profound agitation in the speaker' (2011: 131). Kanafani-Zahar places memory on a register of transformations and possibilities: 'precise, clear, lucid or tumultuous, alternately grave and light [...] numb and lively [...] it wanders and then recoils' (2011: 131). She finally concludes, 'memory has a life of its own' (131), a life that accompanies and becomes one with the life of the victim, in particular when this is also memory's victim, victimised not only by injury, but by official memory's ignorance and neglect of that injury. In this case a personal memory and its testimony is not just a factual story, but a way to reconstruct, repair, and regain an identity. Describing the position of the individual in Lebanese society in relation to memory and testimony, Kanafani-Zahar writes that, whilst "the status of the testimony in Lebanese society is that of an "I" heavily marked by a communitarian "us", nonetheless, the narrativization of memory channels an individual project' (133). Our interviews concentrate on the voice of the individual, rather than assuming that it matches accepted collective narratives.

\section{A suburb in North Metn}

This study relies on memories of ordinary individuals gathered in a small coastal town located in a suburb north of Beirut in North Metn, a district of Mount Lebanon. The fieldwork of our research took place in Spring and Summer 2020 and coincided with a major political crisis and large-scale protests, an almost unprecedented economic and financial crisis, a series of lockdowns imposed to contain the spread of Covid 19, and the aforementioned Beirut blast. Testimonies gathered from May to September have been inevitably affected by the ongoing situation and the interviewees reflected the despair and frustration generated by the current turmoil. To varying degrees, all the individuals interviewed have experienced the war and its consequences, whether directly or indirectly.

Interpretations of the series of conflicts that ravaged Lebanon between 1975 and 1990 vary dramatically in popular, official, and academic renderings. Some argue that the war was not Lebanese because regional and international agendas determined its onset and course. Others contend that it was based not on civil popular mobilisation but on the actions of militias, and others still that it was not one war but a series of 
wars, each with a different agenda. The conflict came to an end through the so-called Ta'if Agreement signed in Ta'if, Saudi Arabia in September 1989 and approved by the Lebanese parliament on 5 November 1989. The agreement describes Lebanon as a sovereign, free, and independent country and a final homeland for all its citizens. Following the Ta'if agreement, the amnesty law of 1991 (General Amnesty Law No. 84/91) granted a general amnesty for crimes perpetrated by all militias and armed groups during the years of the Civil War, before 28 March 1991. This general legal framework has resulted in a system of impunity that has had a significant impact on the post-conflict settlement. As Lyna Comaty recalls, 'Lebanon's post-conflict model has been diagnosed as having failed at building peace' and 'there is neither consensus on the causes of the outbreak of the war, nor on the solutions and methods to build peace (2019: 3). Samir Khalaf describes Lebanon as 'adrift', trapped in a disparaging threefold predicament: alienation from the past, anxiety and unease about the present and uncertainty about the future' (2012: 17). Sami Hermez writes that 'for many in Lebanon, the past persists and threatens to continuously fold into the present' (2017: 150). Rather than amnesia, Hermez speaks of a 'structural power to silence people in society' (149). Because of this, 'civil society was forced to try to redeem these violent acts as crimes, as the only and final space for possible closure and hope for accountability' (191). Evoking the work of Kansteiner, Hermez suggests that memory has to be a way to confront hegemonic systems of power, 'rather than think of the work of memory in terms of denial and amnesia, we might want to remember Gramsci, and to think of the processes being played out as one involving the dominant social order trying to assert hegemonic control over history and truth' (153). Similarly Haugbolle writes that 'Amnesty and amnesia were not just effects of passivity and laissez-faire but also conscious policies applied in the name of national reconciliation' (2010: 71-2).

The dossier of the disappeared and kidnapped deserves particular attention. Despite the progress made recently with the establishment of the National Commission for the Missing and Forcibly Disappeared Persons (Law 105/2018), whose members were nominated in June 2020, the fate of the disappeared remains a lens that reveals a whole series of obstacles. As Kanafani-Zahar writes, 'the impasse over the issue of the disappeared is intimately linked to the fact that militia leaders have become ministers' (2011: 90). Haugbolle concludes, 'when there is no echo of (often traumatic) personal war memories to be found in collective memory, the reality of those memories are liable to be put into doubt' (2010: 72-3), therefore entrenching and perpetuating forms of injustice.

In the case of Lebanon, then, there is a clear antagonism between individual and informal, non-official memories and the State's selective remembering, often intertwined with a political process to shield leaders not only from rival parties/ communities, but from the community they are meant to provide for and protect. In the absence of a shared national narrative, hegemonic narratives have crystallised 
around a set of figures: the leader (al-Zaim), the hero (al-Batal) or resistant (al-Mouqawim), and the martyr (al-Shahid), leaving little space for the memories of ordinary people, including victims. Civilians and their stories in particular have either been written out of history or have been co-opted into political narratives. As Haugbolle notes, 'it was common practice for cultural and political elites to appropriate the story of the civilian victim and imagine his or her memories. In contrast, his or her own voice was seldom heard' (2010: 137). These counter-hegemonic narratives could offer an alternative to the official accounts of the war and offer opportunities to understand further the conflict and its legacy, including Lebanon's present political and social crisis. These personal and family memories could be put at the disposal of the next generations that could complement or even oppose the formal history imposed on the country and its youth. They could contribute to dealing with Lebanon's past and foster social cohesion, truth-seeking, and national reconciliation processes. The case study presented here in particular sheds light on the unknown stories of ordinary people who not only faced the violence committed by the so-called 'foreigner' or 'stranger' (al-Gharib) or enemy ( $a l$-'Adu), but also had to confront the burden and oppression of local militias who were supposed to protect and defend them. This phenomenon is not unique to this town. However, whilst these practices were all too common in many cities and towns in other regions of Lebanon, little research has documented them and in particular very few stories have been gathered from the affected communities. ${ }^{7}$ Whilst in a number of cases militias replaced the State's functions and created infrastructures to provide services, social aid, and healthcare, they also committed abuses against members of their own sect or community, and are known to have committed human rights violations (including killings and kidnappings), most of which remain undocumented to this day. These abuses and violations committed in total impunity were often justified by the militias as ways to maintain order in the absence or inaction, and sometimes with the complicity, of regular troops, local police, or internal security forces. The wealthiest or at least the well-off residents, shops and business owners and traders, in particular those who were not affiliated to these groups, had to pay illegal taxes (Khuwet) and offer pro bono goods and services. Whilst some supported these groups with more or less conviction and paid their dues, many were forced to contribute to the 'war effort', and when they refused to do so

${ }^{7}$ Civil society organisations have made sustained efforts to collect stories as a way of dealing with the past from a truth-seeking and truth-telling perspective. For instance, Act for the Disappeared a local NGO (non-governmental organisation) launched in 2014 a virtual memorial 'Fushat 'Amal' (space for hope) gathering stories of persons missing in war. The International Center for Transitional Justice initiated in 2012 an oral history project 'Badna Naaref' (We Want to Know) to promote intergenerational dialogue on the Lebanese war. See also the ICTJ report, How People Talk About the Lebanon Wars. A Study of the Perceptions and Expectations of Residents in Greater Beirut (2014). 
were threatened and even physically abused. These practices, which benefited from a general lack of accountability, did not disappear with the formal end of the war, but were recycled and adopted by the warlords, their followers, and partisans who had by then occupied official positions within state institutions.

In 2019 the protesters of the October Revolution explicitly rejected the political class in its entirety. The protests also revealed a profound distrust of institutions, which have effectively been occupied by militias that have moved from the battlefield to the heart of the state. For the protestors, the violence that the authorities have used in response to their demands is the continuation of the Civil War militias' practices. One of the slogans chanted during the protests, 'We are the popular revolution, You are the civil war', is indicative of this rejection and demonstrates the awakening of large parts of the Lebanese to the leaders' instrumentalisation of fear and threats presented by the 'other'.

The massive participation in the protests of people coming from different regions and sects has in a way addressed the legacy of the past and put in place the foundation of a true national reconciliation. The parallel between the past oppression and the current management of power is therefore striking. The Beirut blast is read by many as a direct manifestation of the post-war institutional violence, and culture of impunity that accompanies it.

The town selected for this research is representative of other localities across the country, many of which are still under the direct or indirect influence of these political parties, still deploying a diffuse use of violence, with strongmen, 'security men', bodyguards at the service of the party's officials. Dima de Clerck (2012), for instance, discusses the perpetuation of the 'militarization of Lebanese society'. Since the end of the war, thousands of ex-militia fighters and followers were enrolled in the security sector or recruited in the civil administration. Fighters were able to pervade the administration and further corrupt it, 'instead of becoming "civilianised", writes de Clerck. This situation makes the investigation more challenging and justifies why most of the interviewees expressed the intention to remain anonymous.

The authors approached a Lebanese family, whose story centres around Habib, the patriarch, who during the war ran a food wholesale business and managed a family cinema and theatre. The story of this man told by his family and friends has unlocked other stories, individual memories centred around Habib, his shop, his theatre, and his town, but also provides insights into the practices of a local militia during the war. Two generations were interviewed: the first is the generation who were adults at the time of the conflict, mainly parents who had to provide for their children, protect them, and try to transmit to them the same values with which they were raised. The second generation is composed of their children, who were young children or adolescents at the time of the conflict. The latter consider themselves the 'generation 
of the war', a lost generation who experienced the conflict and its aftermaths with bitterness and frustration. The war they knew as children officially ended, but the post-war settlement has delivered a country still mired in unrest.

The study uses semi-structured interviews with individuals, allowing further interventions and comments from their family members who could be present during the discussion. We noticed that conducting the interview in the presence of the family's members is of great interest, as those who witnessed the war participate in the discussions, giving their version of the story, reminding the main interviewee of details and events they could have forgotten. The discussions trigger stories and emotions that become an opportunity for family members, old and young, to talk about forgotten or untold memories. The individual interview could transform into a group meeting, with debates reflecting on incidents, people, and special moments: both the agreeable and the disagreeable, the sad and hurtful events. These discussions between family members have truth-telling and truth-seeking effects on the audience, particularly on the youngest (grandchildren), who were born after the end of the war. In many Lebanese families talking about the war is still an uncomfortable exercise or even taboo, so these intergenerational dialogues triggered by the interviews are likely to have lasting impacts on all members. One man's story facilitated the appearance of multiple individual narratives in a snowball effect. Each interviewee guided the authors to another participant who would complement their narrative, adding information and data in a complex puzzle.

Dolly cannot forget what her father Habib went through during the war to meet the local militia's demands:

he disappeared multiple times, he didn't come back from work at night and my mother used to receive calls that he was only visiting them. She had to write cheques to get him back. For them, even though he was in debt, the bank could give him loans. He used to work hard so they knew he had cash. They hurt my father a lot. ${ }^{8}$

He was continuously forced by the local militia to make financial contributions. When he was unable to do so or refused to, he was invited for a 'coffee' or a 'chat' at the party's regional headquarters. If he did not understand the message of these calls and visits, he was kidnapped and detained in the headquarters offices or in a container until his wife, Angele, delivered a cheque. Angele, 84 years old, still finds it difficult to discuss what happened to her husband, her fears for his safety and how she had to collect the money and write a cheque to save Habib's life.

\footnotetext{
${ }^{8}$ Interview, North Metn, 24 July 2020.
} 
They used to kidnap him saying that he is their 'guest' until I handed them the money. The worst was that the party's partisans who detained my husband were people from the village and one of them was even a relative,

she recalls. ${ }^{9}$ This happened many times and the family had to wait anxiously for him to return home safely. The local militia used to visit every store and every house to collect money on a monthly basis. Ghada recalls how her friend Dania received the visit of the militia's 'money collector' on the day when people were visiting her house to offer condolences for her recently deceased mother.

He stood at the door waiting to collect them money, while people were there paying respect to the dead woman. My friend refused to pay him. The contributions my father paid to the militia have been noted in the store's accounting books. I still have these and copies of checks we paid. ${ }^{10}$

Fouad, 67 years old, remembers how he had to accompany his father to the militia's HQ to pay a 'visit' and how he had to wait for him in the car hoping he would return safe and sound. 'I once took my father there. Their main headquarters in North Metn. I waited there for him. When he came back, he said nothing at all."11 The memory of the humiliation and despair his father and his family experienced for years until his death in 1982 is still vivid and Fouad holds the militia responsible for his father's early death, 'he could have lived longer if the militia didn't make his life impossible'. Dolly and her family still bear a grudge against the political party and its leaders thirty years after the end of the hostilities. 'How can our children and grandchildren forget or forgive those who are responsible for their grandfather's kidnapping, bankruptcy or death?', wonders Ghada, who blames the continuous kidnappings by the local militia for her father's dementia and early death. ${ }^{12}$ Habib's family have transmitted to the younger generation their resentment towards the militia. This is today a very influential political party in the North Metn region and considers itself currently as an 'opposition party' with a clean record fighting the State's corruption and calling for accountability. The parents make sure that their children are aware of the party's legacy of abuses and violations. This heritage is of course neither limited to the North Metn region, nor to this particular militia; it is present in many families and communities across Lebanon. Since October 2019, young people have expressed in street protests and on social media their distrust of the current ruling class, drawing the parallel between their war practices and the mismanagement, wrongdoings, and policies of the past thirty years.

\footnotetext{
${ }^{9}$ Interview, North Metn, 5 July 2020.

${ }^{10}$ Interview, North Metn, 10 July 2020.

${ }^{11}$ Interview, North Metn, 10 July 2020.

${ }^{12}$ Interview, North Metn, 10 July 2020.
} 
Testimonies such as the ones presented here can be read in terms of the 'subjugated knowledges' and 'counter-memories' discussed by Michel Foucault (2003: 7). Foucault offers a twofold definition of subjugated knowledges: 'historical contents that have been buried' and 'naive knowledges', 'knowledges from below' (7). It is the reappearance of this differential knowledge (8) that makes critique possible. As José Medina writes, 'Foucault places practices of remembering and forgetting in the context of power relations in such a way that possibilities of resistance and subversion are brought to the fore' (2011: 10). Drawing on Foucault's work, Medina further suggests that memories could challenge coercive epistemic frameworks and that therefore it is crucial to mobilise those whose memories do not fit existing historical narratives, 'scattered, marginalized publics, tapping into the critical potential of dejected experiences and memories' (11). Where official histories 'create and maintain the unity and continuity of a political body' (14), counter-histories try to challenge and interrupt this continuity.

Three major events were mentioned during the interviews as having had the greatest impact on this North Metn town and its residents. The first took place in 1975 during the early stages of the war, when local militias fought for the control of the town resulting in its first victims and wounded. The second event happened a few months later. Fouad, a medical student at the time of the incident, recounts how a delegation representing the town had visited the leader of the main militia in the region to ask for help to get rid of a rival political party whose behaviour had become intolerable to many. To deploy its forces the leader asked for a large sum of money that the town could not afford. ${ }^{13}$ The delegation decided then to create an independent group that would guarantee the safety of the town. The militia leader was not happy with this decision and a few days later his militia killed four young men, associated with the independent group formed to defend the town. To claim the assassinations and assert their power, the militiamen rushed to hang their leader's poster over a building that the independent group used as headquarters. For Ghada, who was 16 at the time, it was the first encounter with the war. She helped transport the killed and the wounded to the city's hospital with a group of friends. She recalls the story without hiding her emotion: 'I still remember that day, the boys lying on the ground drowning in their blood and how we rushed to the nearby hospital. We knew them all. ${ }^{14}$ The third event took place on 17 August 1985 with the explosion of a 250-kilogram hexogen bomb placed in front of a busy supermarket, resulting in the killing of 32 people with 85 wounded. ${ }^{15}$ Many in the area suspected the bombing to be the work of the local

\footnotetext{
${ }^{13}$ Interview, North Metn, 10 July 2020.

${ }^{14}$ Interview, North Metn, 10 July 2020.

${ }^{15}$ AnNahar (Lebanese newspaper), 18 and 19 August 1985. Cited by ICTJ (2013).
} 
militia in its struggle for power in the region. Fouad says: 'I think it was them, because all that was being done to Habib [his father-in-law] was done to many in the region, including to the owner of this supermarket chain. I think he had stopped paying, he was fed up. ${ }^{16}$ Thirty-five years later, the families of the victims refuse to forget, and the younger generation bears the trauma of the crimes committed against their relatives and town. Nothing has been done to address the legacy of abuses committed by the militias that were in principle committed to protecting the local population. It is significant that, in the elections that have taken place in the past three decades, the town's voters have always avoided voting for the candidates representing the old militia and political party. It is their way of expressing their bitterness and in a way addressing the war's heritage.

The testimonies and stories gathered here signal to something true of Lebanon's Civil War, but applicable to a broader context. In the context of changing memory cultures in the Middle East, Haugbolle writes that, whilst the national sphere is often still saturated with state-enforced rhetoric, 'increased access to information, means of expression and political participation are introducing previously "intimate" views of the past into public deliberation, thereby challenging state-centred narratives of national memory' (Haugbolle \& Hastrup 2008: 137). In most cases the state's control relegates disruptive memories to the margins of public discourse and erects homogeneous accounts as walls against potential attacks. However, as Achille Mbembe writes, every archive, "is at once a breaching (frayage), an opening, and a separation, a fissure and a breaking, a crazing and a disjunction [...] no archive exists without its cracks (lézardes). One enters into it as though through a narrow door, with the hope of penetrating in depth the thickness of the event and its cavities' (2019: 172). Memory therefore becomes one of the tools that artists and activists alike can use to revisit and renew 'the rich legacy of contentious politics and radicalism' (Haugbolle 2019: 287).

\section{War, experience, and the everyday}

It is precisely from these margins that subversive memories can begin to exploit the cracks in the archive of national memory. In a similar way and notwithstanding its limited scope, this study also shows that attending to personal memories offers important elements for a study of war as a set of experiences felt in the everyday. Personal memories, normally marginalised in global politics, but also in historiographies dedicated to armed conflicts, reveal war as an experiential continuum. As feminist scholarship has emphasised, "war is a social activity of collective violence around

\footnotetext{
${ }^{16}$ Interview, North Metn, 10 July 2020.
} 
which a wide variety of bodily experiences are created, altered, and can themselves create or constitute war' (Sylvester 2013: 65). This approach allows for a renewed look at conflict and, as Christine Sylvester suggests, can 'jog the mind into a different quadrant of knowing and understanding' (2010: 123).

Thinking about conflict as experienced means bringing to the fore elements of war that are traditionally excluded, looking for deeper ways in which war reaches into society, means understanding conflict not as a discrete event, but as a continuum, therefore starting earlier and going on for longer and populated by a wider variety of actors and means. It also means abandoning the idea that we can always fashion a coherent narrative, but that we have to acknowledge the complex and pervasive (everyday) nature of conflict. As Laura Sjoberg writes: 'starting with the lives of people, gives us not just a different method of studying war, but a different view of war, one which draws our attention away from national interest politics to the individual that touches and is touched by war physically and emotionally' (2013: 253).

To study war as experience requires, therefore, that the human body come into focus as a unit that has agency in war and is also the target of war's violence. It also means introducing and doing justice to the affective elements of armed conflict. The study of individual memories can contribute profoundly to reorienting our understanding of war, showing, for instance, how militarisation occupies everyday life and opening up that 'different realm of thinking' (271) alluded to by Sjoberg.

\section{References}

Bell, D. (2009), 'Introduction: Violence and Memory', Millennium: Journal of International Studies, 38(2): 345-60. https://doi.org/10.1177/0305829809347541

Comaty, Lyna (2019), Post-conflict Transition in Lebanon: The Disappeared of the Civil War (London, Routledge). https://doi.org/10.4324/9781315386027

de Clerck, Dima (2012), 'Ex-militia Fighters in Post-war Lebanon', Accord, 24: 24-6.

Foucault, Michel (2003), Society Must be Defended (London, Palgrave Macmillan).

Green, Anna (2004), 'Individual Remembering and "Collective Memory": Theoretical Presuppositions and Contemporary Debates', Oral History, 32(2, Memory and Society): 35-44

Haugbolle, Sune (2010), War and Memory in Lebanon (Cambridge, Cambridge University Press). https://doi.org/10.1017/CBO9780511676598

Haugbolle, Sune (2019), 'Memory Studies in the Middle East: Where Are We Coming From and Where Are We Going?', Middle East Critique, 28(3): 279-88.

https://doi.org/10.1080/19436149.2019.1633742

Haugbolle, Sune \& Hastrup, Andres (2008), 'Introduction: Outlines of a New Politics of Memory in the Middle East', Mediterranean Politics, 13(2): 133-49. https://doi.org/10.1080/13629390802127497

Hermez, Sami (2017), War Is Coming: Between Past and Future Violence in Lebanon (Philadelphia, PA, Pennsylvania University Press). https://doi.org/10.9783/9780812293685 
ICTJ (International Center for Transitional Justice) (2013), Lebanon's Legacy of Political Violence. A Mapping of Serious Violations of International Human Rights and Humanitarian Law in Lebanon (1975-2008).

https://www.ictj.org/sites/default/files/ICTJ-Report-Lebanon-Mapping-2013-EN_0.pdf

ICTJ (International Center for Transitional Justice) (2014), How People Talk About the Lebanon Wars. A Study of the Perceptions and Expectations of Residents in Greater Beirut.

https://www.ictj.org/sites/default/files/ICTJ-Lebanon-FocusGroup-Report-2014.pdf

Ismail, Salwa (2018), The Rule of Violence: Subjectivity, Memory and Government in Syria (Cambridge, Cambridge University Press). https://doi.org/10.1017/9781139424721

Kanafani-Zahar, Aïda (2011), Liban, la guerre et la mémoire (Rennes, Presses Universitaires de Rennes).

Keightley, Emily \& Pickering, Michael (2012), The Mnemonic Imagination: Remembering as Creative

Practice (New York, Palgrave Macmillan). https://doi.org/10.1057/9781137271549

Khalaf, Samir (2012), Lebanon Adrift: From Battleground to Playground (London, Saqi Books).

Mbembe, Achille (2019), Necropolitics (Durham, NC, Duke University Press). https://doi.org/10.1215/9781478007227

Medina, José (2011), 'Toward a Foucaultian Epistemology of Resistance: Counter-memory, Epistemic Friction, and Guerrilla Pluralism', Foucault Studies, 12: 9-35. https://doi.org/10.22439/fs.v0i12.3335

Ryan, Lorraine (2010), 'Memory, Power and Resistance: The Anatomy of a Tripartite Relationship', Memory Studies, 4(2): 154-69. https://doi.org/10.1177/1750698010366502

Sjoberg, Laura (2013), Gendering Global Conflict: Toward a Feminist Theory of War (New York, Columbia University Press).

Stern, Steve (2010), Reckoning with Pinochet: The Memory Question in Democratic Chile (Durham, NC, Duke University Press). https://doi.org/10.1215/9780822391777

Sylvester, Christine (2010), Experiencing War (London, Routledge). https://doi.org/10.4324/9780203839997

Sylvester, Christine (2013), War as Experience: Contributions from International Relations and Feminist Analysis (London, Routledge). https://doi.org/10.4324/9780203100943

Van Dijck, José (2007), Mediated Memories in the Digital Age (Stanford, CA, Stanford University Press).

To cite the article: Carmen Hassoun Abou Jaoude and Daniele Rugo (2021), 'Marginal memories of Lebanon's Civil War: challenging hegemonic narratives in a small town in North Metn', Journal of the British Academy, 9(s3): 11-27.

DOI https://doi.org/10.5871/jba/009s3.011

Journal of the British Academy (ISSN 2052-7217) is published by The British Academy, 10-11 Carlton House Terrace, London, SW1Y 5AH www.thebritishacademy.ac.uk 
